\begin{tabular}{l} 
RCCS \\
\hline Annual Review
\end{tabular}

\section{RCCS Annual Review}

A selection from the Portuguese journal Revista Crítica de Ciências Sociais

$6 \mid 2014$

Issue no. 6

\title{
Free Software Culture and Development: An Analysis on Potentials and Limits in and Beyond the Context of the "New Economy"
}

\section{Leonardo Santos de Lima}

Translator. João Paulo Moreira

\section{OpenEdition}

\section{Journals}

Electronic version

URL: http://journals.openedition.org/rccsar/571

DOI: $10.4000 /$ rccsar. 571

ISSN: $1647-3175$

\section{Publisher}

Centro de Estudos Sociais da Universidade de Coimbra

\section{Electronic reference}

Leonardo Santos de Lima, «Free Software Culture and Development: An Analysis on Potentials and

Limits in and Beyond the Context of the "New Economy" », RCCS Annual Review [Online], 6 | 2014,

Online since 01 October 2014, connection on 19 April 2019. URL : http://journals.openedition.org/ rccsar/571 ; DOI : 10.4000/rccsar.571 
Leonardo Santos de Lima

Federal University of Rio Grande do Sul (UFRGS), Brazil

\title{
Free Software Culture and Development: An Analysis on Potentials and Limits in and Beyond the Context of the "New Economy"*
}

\begin{abstract}
This article analyzes the potentials and limits of the free software culture and the products derived from it in what concerns the promotion of economic and social development in the context of the "new economy" and the alternatives to it. It examines the incentives and constraints to innovation, in its different senses, generated by free softwares as goods technically distinct from proprietary software and developed on the basis of specific values and interests. It also reflects on their limitations and capabilities in relation of the promotion of development strategies aimed not only at economic growth based on technological improvement, but especially at generating social opportunities.
\end{abstract}

Keywords: free software; new economy; innovation; economic and social development; information and communication technology; access asymmetry.

\section{Introduction: The "new economy" context}

In the last decades of the twentieth century, a structured set of changes combined with the development of new information and communication technologies (NICTs) to accelerate the process of broad, collective transformations occurring in the world at large. In the new setting, countries across the planet steadily embarked on a dynamic of increasing interdependence that caused the emergence of new forms of interaction between the cultural, political and economic fields. Although the changes in question did not affect every world region to the same degree and cannot be said to be the result of a straightforward, irreversible complex of global transformations (Cocco, 2011; Santos, 2011), it is safe to say that they are the expression of a number of phenomena that are becoming hegemonic and whose consequences and characteristics cannot be ignored, given their impact on decisionmaking, especially in politically and economically dominant societies (Guesser, 2011).

Because of this dynamic of collective transformations coupled with rapid technical development, a "new economy" took shape. In the new environment, profitability and competitiveness - "the actual determinants of technological innovation and productivity growth" (Castells, 2010: 136) - are achieved through improved technology, made possible by the accumulation of knowledge and the increasing complexity of information processing. A knowledge-centered economy thus emerged, its development based on the transformation

\footnotetext{
* Article published in RCCS 102 (December 2013).
} 
of information into innovation, which laid the foundations for what could be termed a "knowledge economy" (Julien, 2010).

From then on, the pursuit of economic innovation - based on the ability to speed up the whole process of rolling out new products and services across the market - has become the main strategy for business expansion and the most important means of beating the competition. The "new economy" is inextricable from the unending search for new potential consumers, seen as opportunities to add to the amount of accumulated capital. This largely explains why the new technologies get to be created and disseminated at such great speed (Castells, 2001).

At the same time, the hegemonic economic context also contains multiple tensions arising from its internal constraints, which in turn derive, among other reasons, from the fact that the legitimacy of any challenge to the social order as dictated by the market and by technological advances is undermined (Martín-Barbero, 2006). Within that order extending from the center to the peripheries, "globalization" builds upon a dynamic that connects everything it deems instrumentally valuable - individuals, companies and institutions - while disconnecting all that is not perceived as relevant under this logic (Bauman, 1998). Thus the "new economy" and its avatars, such as the concepts of "society" and "knowledge economy," basically depend on the inertia of the traditional systems that define the conditions for knowledge production and reproduction, which are often marked by all sorts of authoritarianisms and impositions (Orozco Gómez, 2006).

In the current economic environment, states and international regulatory bodies play a major role in perpetuating the existing objective conditions with regard to knowledge, as it is they that stipulate institutional restrictions to the access and dissemination of information and knowledge, turning them into commodities (Albagli and Maciel, 2011). Thus, the level of control and concentration of the resources seen as strategic for the "new economy" has increased, through a strengthening of the mechanisms for protecting intellectual property rights, as has been the case with software development since software started being privatized on a large scale a few decades ago.

While it is clear that there is a collective downside to the emergence of the new forms of domination and inequality observed in the aftermath of the capitalist restructuring of the late $20^{\text {th }}$ century and during the globalization process that shaped the "new economy" in the same period, the changes currently under way present us with a complex set of phenomena 
that are at once negative and positive, as well as deeply ambiguous and unpredictable at times (Kellner, 2003). The complexity of this whole context therefore requires a critical perspective that allows for its various aspects to be properly assessed. Furthermore, such a perspective should remain skeptical of the legitimation of the new environment's ideological discourse while acknowledging the relevance of the phenomena that constitute it, in order to be able to assert and explore its positive aspects (Best and Kellner, 2001; Kellner, 2002).

Since the new information and communication technologies play a leading role as a resource used by globalization to mobilize various flows of goods, information, people and capital in increasingly interconnected societies, economies and cultures (Castells, 2010), the complexity of our current scenario is inevitably present also in the modes of creating and appropriating these technical innovations, which may either cause great harm to the human species or generate new ideas, wealth and major developments in the global arena (Kellner, 2003). Thus, the history of how personal computers (PCs) were first created and popularized, the practices and values of the early software development communities, and the emergence and spread of the Internet, ${ }^{1}$ all show that the development of NICTs is the product of a variety of social and cultural interactions that are partly conflicting, partly complementary, and partly also a result of the logic of the "new economy."

Among the sociocultural phenomena incubated in the period of far-reaching changes that marked these past few decades, the culture of free software stands out for its ability to promote both proximity to and an almost insurmountable distance from the sphere of the organizations, institutions and values that are dominant in the contemporary economic scene. Thus, unlike those approaches that tend to focus on only one side of the coin, the present article examines the multiple aspects of the potentials and limits of free software culture, in and beyond the logic of the "new economy." In other words, it looks into how free software culture promotes development through strategies that are embedded in an environment of economic competition and characterized by the constant need to generate new knowledge, and it analyses its potential for social inclusion and empowerment, rather than dwelling solely on the restrictions of a logic based on the perpetuation of widespread asymmetries and exclusions.

\footnotetext{
${ }^{1}$ On the emergence and development of personal computers, see Breton (1991), Negroponte (1995) and Balduci (2000). On the history and culture of the Internet, see Castells (2001, 2010); Cardon (2012). On the origin of "free software," see Kelty (2008), Chopra and Dexter (2010) and Coleman (2010).
} 


\section{Free software culture: Origins and current situation}

As Coleman (2010) points out, until the 1980s the software developed in the United States was seldom subject to copyright and patents, which made it possible for programmers and hackers to work together, perfecting their source codes. ${ }^{2}$ From then on, however, private companies began to close down those programs under the laws of Intellectual Property (IP), which were spreading rapidly at the time. Richard Stallman, a hacker and a programmer at MIT's Artificial Intelligence Laboratory, responded by starting a movement for the creation and preservation of what became known as free software (Silveira, 2004; Coleman, 2010).

For Stallman and his followers, the source code and the potential for sharing were the basis for the strong connection between the community of developers and the culture of programming, which was rapidly falling apart at the time. In 1983, in an attempt to prevent this culture from becoming extinct, Stallman launched an alternative license, GNU (General Public License), also known as copyleft. By starting GNU, Stallman created "a license whereby he kept the copyright of his code while allowing free distribution, provided that such freedom was extended to every user" (Coleman, 2010: 133). In other words, he used the weapons of his "enemies" against them. ${ }^{3}$

After Linux (a UNIX-based operating system developed by Linus Torvalds) ${ }^{4}$ first arrived on the scene in 1991, there was a proliferation of voluntary associations inspired by the ideology of free software (Silveira, 2004). At the same time, from the early 1990s programmers and hackers alike became more and more acquainted with the laws governing free software and Intellectual Property Rights so as to protect themselves against them. These laws and regulations were becoming increasingly far-reaching and restrictive, while copyleft evolved in the opposite direction, and in doing so brought insecurity to the big

\footnotetext{
${ }^{2}$ According to Coleman (2010: 132), the source code is the "set of underlying functions that make computer programs work." One may also define it as a "set of words or symbols written in an orderly, logical fashion, containing instructions in one of the existing programming languages." Accessed on 03.02.2014 at http://pt.wikipedia.org/wiki/Código fonte.

${ }^{3}$ The GNU Manifesto, which marks the beginning of the Free Software Movement, lists "four freedoms" its followers are supposed to respect in the process of sharing software production: "The freedom to run the program, for any purpose" (freedom \#0); "The freedom to study how the program works, and adapt it to your needs" (freedom \#1); [...] "The freedom to redistribute copies so you can help your neighbor" (freedom \#2); "The freedom to improve the program, and release your improvements to the public, so that the whole community benefits" (Freedom \#3) (Murillo, 2010: 77).

${ }^{4}$ An operating system developed by Bell Labs, UNIX laid the foundations for the development of the Internet (Castells, 2001: 16).
} 
corporations, where the advantages of open source were already being acknowledged (Coleman, 2010).

The tensions arising from the spread of copyleft in the face of private corporate interests led a group of hackers, with Eric Raymond as their most famous representative, to launch the Open Source Initiative (OSI) in 1998. Their purpose was to try to extricate free software which they termed Open Source Software - from its moral and political significance. The group adopted a pragmatic approach that valued open source for its technical advantages, in an effort to make it "more palatable to the corporate world" (Coleman, 2010: 141).

The internal divisions that affected the Free Software Movement (MSL) launched by Stallman in 1985, as a result of the creation of the Open Source Initiative (OSI) and the emergence of the Open Source Software, show the importance of the role played by pragmatism as a central value for many copyleft advocates, who attribute the quality of their work to their higher level of organization and to the type of software developed under this logic, in contrast to the mode of production of large commercial companies. Besides, such pragmatism, which clearly has to do with the "free spirit" that pervades this culture, makes it possible for many users to claim the right to use their applications for commercial purposes without betraying the software's most basic principle: open access to all the information contained in the program, including the freedom to modify it and use it at will.

Briefly put, unlike proprietary software, the culture of free software is based on practices and values that, while differing markedly from those of copyright-protected software, also permit interconnections with the logic of the latter, as is the case with Open Source Software. Thus the distinctive character of "free software" as understood by Stallman and MSL has a lot more to do with ideological issues than with technical differences, since both types share the same historical and social roots and a number of core values built around the idea of freedom.

According to the information available on SourceForge.net, the largest repository of open source code on the Internet, there were 180,000 registered projects and 1.9 million registered users in 2008 (Johnson, 2010). In 2003 there were about 400,000 free software developers from more than 90 countries (Silveira, 2003). Moreover, since early in 2000 a number of companies around the world have been making at least partial use of copyleft systems: these include several large groups, both private and public, such as Lufthansa, Walmart, Dow Jones, Amazon.com, Banco do Brasil, and Petrobrás; government agencies 
and institutions like NASA and the Pentagon; and various Ministries, State Assemblies and Federal Universities in Brazil, among others (Guesser, 2011).

In the case of Brazil, the use of free software increased both in public agencies and in the corporate world as a result of the growth of demand and the market, after the Federal Government issued the Free Software Implementation Guidelines in 2003. The government's preference for this type of software was thus made official, its ultimate goal being the adoption of open standards in view of the advantages ${ }^{5}$ inherent in open source software (Miranda et al., 2008).

At the same time, some of the most important contributions in the history of free software culture, with an impact at both the social and economic level, have been reflected in the changes effected by this culture since it first emerged, both in the institutional sphere - with the creation of the GNU license within the existing legal framework - and in the organizational and technological spheres. The innovative nature of the latter changes is particularly noticeable in the way the Internet evolved.

\section{The Internet and the contributions of free software}

As pointed out by Castells (2001), the Internet could never have originated in the business world. This becomes obvious when we think that in its early years, in the 1960s and 1970s, its technology was too bold and required very high investment costs, and thus it was incompatible with organizations driven by profit and short- or medium-term returns. Only the state could afford the huge resources and the risks involved in launching the Internet, which explains why it emerged in the political and military climate of Cold War America. At the time the United States government was committed to mobilizing research resources in association with the country's academic institutions, its goal being to achieve technological and military superiority over the Soviet Union.

The beginnings of this trajectory cannot be fully understood unless mention is made of the unwonted encounter, in US research laboratories, between big science and the libertarian countercultural trends that shaped the first decades of the second half of the $20^{\text {th }}$ century. That "unlikely intersection" (Castells, 2001: 17) established a link between, on the one hand, the cutting-edge scientific research carried out by the academic elite at US

\footnotetext{
${ }^{5}$ For a discussion of these advantages and benefits, see below.
} 
universities - which tended to work on large, government-funded military projects - and on the other a culture or an ideology based on the unwavering defense of individual freedom and "a systematic distrust of government" (ibidem: 33).

Thus, one decisive step toward building the computer networks that were to give rise to the Internet was the creation of a community of users, made up mostly of students and academic researchers, who used the UNIX operating system. This is how

UNIX became the lingua franca of most computer science departments, and students soon became adept at its manipulation. Then, in 1978 Bell distributed its UUCP program (UNIX-toUNIX copy) allowing computers to copy files from each other. On the basis of UUCP, in 1979, four students [...] designed a program for communication between UNIX computers. An improved version of this program was distributed freely at a UNIX users' conference in 1980. This allowed the formation of computer communication networks, Usenet News [...] thus considerably broadening the practice of computer communication. (Castells, 2001: 13)

Here we can observe how the free software culture had a direct influence not only in the creation of UNIX - a program that was to play a crucial role in the development of Internet technology - but also in the structuring of a number of networks characterized by flexibility and by practices of free sharing of information among its users. Similarly, as seen above, the development of UNIX-based Linux was to raise awareness, among hackers and geeks at first, and later in the business community and society in general, of the full potential of shared production, which is a hallmark of the universe of software production.

Moreover, although the exponential expansion of the Internet did not take place until the 1990s, when privatization turned the new technology into a truly "global network," its rapid spread throughout society was not caused by the advent of commercial operations alone, since

[...] by 1990 the Internet was still difficult to use for the uninitiated. There was very limited graphic transmission capability, and it was extremely hard to locate and retrieve information. A new technological leap allowed the diffusion of the Internet into the mainstream of society: the design of a new application, the world wide web, organizing the Internet sites' content by information rather than by location, then providing users with an easy search system to locate the desired information. (Castells, 2010: 50)

The "www" consists of a browser/editing program based on the logic of hypertext and multimedia technologies, hence the software's audiovisual nature. Once created, it was immediately distributed throughout the net, free of charge (ibidem: 51). From the moment it was launched under a copyleft license, many hackers began developing their own browsers, seeking in many cases to explore their future business potential. 
The first browser to become popular was Mosaic, designed to run on personal computers and released free of charge in 1993. Within a year it already had millions of users. Soon after that, its creators, who had joined Jim Clark (a prominent Silicon Valley entrepreneur) to start Mosaic Communications, launched Netscape Navigator through the Netscape Communications Corporation (formerly Mosaic). In 1995 Microsoft made its debut in the world of the Internet, releasing Internet Explorer with Windows 95. In 1998, financial difficulties led Netscape to adopt measures that were unprecedented at the time for a private information technology company: in an effort to recover from the slump in its share prices, it released "its browser's source code under an open source license" (Coleman, 2010: 141). Eventually Netscape Navigator was followed by Mozilla Firefox (currently under a copyleft license), which has become one of the most widely used browsers in the world.

Conversely, until the dawn of the $21^{\text {st }}$ century the web - the graphical portion of the Internet - was dominated by large commercial portals such as Yahoo! and America Online (AOL), both launched in the US in 1996, and Universo Online (UOL), released that same year in Brazil. The market for $\mathrm{HTML}^{6}$ programming and for website and webpage designing went through a period of dramatic growth at around the same time.

Thus, during the web's first phase, Internet users were primarily receivers and consumers of information, products and services made available by companies and other entities (Campos, 2009). Since around the beginning of the $21^{\text {st }}$ century, however, the general attitude of major content providers, Internet companies, and users themselves changed sharply in comparison to that early period, which became known as Web 1.0.

With the second generation of the "world web," information technology companies began to awaken to the possibilities of content creation based on the users' active and collaborative participation, through the incorporation of Internet uses and practices associated with the open, free production culture that marked the beginnings of the web and lies at the roots of free software. Such uses and practices eventually shaped what is called the Web 2.0, and made possible the emergence of world-spanning, commercially appealing, information-sharing sites like YouTube and Facebook. As web pioneer Dale Doughherty clearly understood as early as 2004, "far from having 'crashed', the web was

\footnotetext{
${ }^{6}$ HyperText Markup Language, a format specifically designed for hypertext documents, relies on the Internet's proverbial flexibility, which allows the new shared format to accommodate specific computer languages (Castells, 2010: 51).
} 
more important than ever, with exciting new applications and sites popping up with surprising regularity" (O'Reilly, 2005: 1).

Thus, the history of the development of the Internet serves to illustrate the idea that innovations tend to cause companies to move beyond their own horizons and resort to a vast network of collaborators, "in a structure that is similar to a highly diverse and complex ecosystem, [and] whose commercial dimension is but one of its many facets" (Arbix, 2010: 171). As far as the Internet is concerned, the organizational, production and distribution logic underlying the world of free software, rather than going against the development strategies of the "new economy" proved essential in fostering those strategies, even when it was not primarily driven by economic gain - as is the case with proprietary software production and large Internet companies.

\section{Free software culture, innovation and development: In and beyond the "new economy"}

The idea of innovation is inseparable from the development strategies designed to ensure that countries perform well in the context of the "new economy" and globalization. As a rule, innovation can be understood either in the plainest sense, drawing on such notions as "rearrangement," "combination" and "exploration" (Arbix, 2010: 168), or in connection with the market - be it as "the economic application of a new idea" (Black, 2009: 230), be it in terms of "every new process, discovery, product or service - whether high-tech, low-tech or no-tech - that adds economic value to the company" (Arbix, 2010: 170).

With these definitions in mind, it seems appropriate, as a first step, to look into the potential and limits of free software culture with regard to the promotion of development. Our point of departure will be the idea of innovation in an environment of economic competition, where the production of new knowledge is used as the chief raw material of the innovative process. Next this culture will be analyzed from another angle: that of innovation understood in a broader sense, i.e., not confined within the current prevailing model of economic and technological development, but focused, instead, on overcoming the reproduction of the asymmetries and exclusions that define the dynamics whereby information and knowledge, both specialized and non-specialized, are produced and disseminated (Albagli and Maciel, 2011).

Regarding the first topic, Yochai Benkler's The Wealth of Networks (2006) highlights the main attributes and benefits of today's "networked information economy," thus redeeming, 
at least in part, the values and assumptions of the so-called "new economy." The author argues that decentralized individual action is a lot more important now than in previous periods, when the traditional paradigms of industrial production were the rule. More specifically, according to Benkler, today's environment is characterized by the emergence of a "new invisible hand" generated by an economy that is based on the immaterial and is fundamentally communicative in nature, and which, moreover, rests on the potential of networks to give shape to a free, productive society under new technological and economic conditions.

On the other hand, the greatest potential of this new networked system of which Benkler speaks, lies mostly in the unprecedented possibility of exchanging a very large and diverse amount of information at a low cost. For this to happen, existing conditions must allow the proliferation of sustainable collaborations and resource sharing among individuals and groups who are in a position to be independent producers, based on models such as copyleft and commons, instead of the institutional arrangements confined to today's prevailing notions of property. These, for Benkler (2006), are the positive traits of the current period in comparison with previous production systems, as well as its major advantages in terms of generating wealth and development.

In view of these traits, the permission to freely modify the source code of open source software in a competitive market amounts to a number of advantages over proprietary software, which tends do be confined by the constraints of intellectual property rights. In such a context, where economic and technological innovation based on the intensive use of knowledge plays a central role, the advantages of free software hinge mainly on the possibility of its being used for the purposes each player in the market sees as best for their interests. For entrepreneurs working with software development, this means, among other gains, the extra advantage of possessing, and also of offering their clients, a variety of customized programs and services (Ferraz, 2002; Mendes, 2006; Guesser, 2011). By the same token, both the speeding up of the learning process made possible by the access to the source code and its documentation, and the fact that developers participate in various free software production projects - thus tacitly sharing expertise through contact with other professionals - are key factors for promoting innovation in companies that exist in an economy based on intangibles (Mendes, 2006).

Furthermore, it should be pointed out that opting for copyleft licensed software does not 
mean that only this type of program is going to be used. In some companies it is common for it to exist side by side with software protected by intellectual property rights, without the former being affected by this in a negative way. At the same time, the fact that it is no longer necessary to incur the cost of many licenses for operating systems and applications, or to acquire new hardware - because open systems, owing to their enhanced performance, require less processing capacity (Ferraz, 2002; Mendes, 2006; Guesser, 2011) - means that company resources can be redirected so as to invest in innovation rather than financing large corporations through the purchase of proprietary software.

Still, one major hindrance to the spread of free software and the recognition of its potential for generating economic and technological innovation has to do with the way in which the software market structured itself over the last decades, following a pattern of monopolistic expansion. ${ }^{7}$ As Guesser (2011) pointedly observes, free software is not synonymous with cost-free software, as its use - even when no customized software had to be developed - inevitably carries costs relating to training, technical support and basic maintenance. Therefore, given that only a few professionals have the skills to work with the programs in question, the lack of competition results in much higher prices being charged for these services than for jobs related to software with a market monopoly, such as the Windows operating system and the application packages that come with it.

It is also important to stress the risks arising from the misappropriation of works generated from free software. These risks arise primarily from the use of the core idea of the source code, followed by its being "closed" when new software is rewritten by a developer and incorporated into the idea of the original source code in slightly different form. The new software is then marketed as if it had been wholly created by the new developer under the protection of intellectual property rights (Mendes, 2006). Therefore, private misappropriation increases the tendency toward the commodification of immaterial goods spearheaded by the large software industries, and is consistent with the logic of capitalism in terms of turning products into commodities, while also not deviating from the pattern of domination of Southern countries by Northern countries (ibidem).

In connection with these issues, it seems appropriate to consider, as part of a bigger

\footnotetext{
${ }^{7}$ To illustrate: In 2014, over $90 \%$ of personal computer users around the world are using some version of the Windows operating system. See "Desktop Browser Share Trend," NetMarketShare. Accessed on 03.02.2014 at http://www.netmarketshare.com.
} 
picture - though still well within the scope of economic dynamics - the potential of free software culture as it relates to the problems that, according to Amartya Sen (2000: 144), have to do with the "inequality in the distribution of substantive freedoms and capabilities." For if, on the one hand, these freedoms and capabilities can be fostered, for example, by the possibility of free trade and free choice of employment under ideal conditions of market competition (Sen, 2000), on the other hand the absence of said conditions can severely curtail those freedoms and arrest the development of those capabilities, through mechanisms that favor the preservation of property rights and the formation of monopolies.

Free software culture has the capacity to act as a regulator of such distortions, since it can be an important tool to keep markets efficient to the extent that it helps make them more competitive and less monopolistic. By the same token, coordination with government initiatives - as is the case in Brazil, with the establishment of technical committees aimed at coordinating the planning and implementation of free software - can pave the way for its products and services, encourage the development of local technology, and promote free competition among suppliers (Miranda et al., 2008).

Specifically regarding the distribution of capabilities, i.e., the potential to use not only income, but a variety of means such as knowledge (Sen, 2000), the technical properties of free software have the advantage of enabling increased interconnectivity and flexibility in the access to and exchange of resources at a low cost by a virtually unlimited number of individuals, as envisaged by Benkler (2006) in his networked production model. In order for this to occur, however, the technical properties need to work in tandem with non-digital namely social and cultural - variables aimed at a better distribution of power in society (Sassen, 2011). In light of this, the "culture" underlying open source and its products proves vital, because the values and interests that define it allow for the technical capabilities that characterize these programs to be combined with the imperative to develop human capabilities to the full.

Thus the debate on free software development should take us beyond a mere consideration of the possibilities and limits pertaining to the competitive environment of markets and technological innovation. Another kind of analytical angle is then necessary. According to this second approach, the question of inequality in the distribution of substantive freedoms and capabilities calls for a rethinking of the narrow definitions of innovation as used in the realms of the market and technology, so that we can move toward 
an understanding of the concept's full meaning.

From this perspective, the idea of innovation may be broadly defined as any action/initiative meant to create something novel for the purpose of solving problems or providing for the needs of individuals and/or groups, based on practical and/or theoretical knowledge - in other words, in consonance with a given society's (territory/culture) stage of technical development and knowledge at a given historical moment (Baumgarten \& Santos de Lima, 2014). It is therefore related to the notion of development, not in the customary sense of progress (viewed as a linear, unequivocal transformation process), but rather as a historical shift toward solving multiple problems and social needs (ibidem). Besides, this approach brings to the fore the capacity individuals and groups have to organize themselves in order to achieve social gains and a (re)distribution of power, which to a large extent depend on how well-informed they are and their level of education - that is, on the distribution of knowledge (Maciel, 2005).

Based on this broadened conception of innovation, it becomes possible to devote all the potential of the culture of free software and related products to the preservation of the substantive freedoms and the distribution of capabilities, in pursuit of correspondingly broader goals, which is to say, with the aim of creating social opportunities.

The possibility of creating such opportunities becomes fairly clear when free software is viewed as a tool for inclusion and the reduction of social inequalities, and when the latter is seen in terms of bridging the digital divide. But as Warschauer rightly explains, meaningful access to new technologies entails a lot more than providing computer resources such as hardware, software and Internet access, because

[it] is embedded in a complex array of factors encompassing physical, digital, human, and social resources and relationships. Content and language, literacy and education, and community and institutional structures must all be taken into account if meaningful access to new technologies is to be provided. (2004: 6)

To put it succinctly, contrary to naive notions that tend to focus exclusively on the question of technological dissemination, digital exclusion and inequality do not stem primarily from lack of, or unequal access to, material or immaterial resources strictly pertaining to the realm of information technology, but are rather the result of poor distribution of resources and capabilities in general.

But while it is important to be aware of the limitations of the role of free software in 
development strategies grounded exclusively on the acquisition of new technological goods, it is also important to point out that the diffusion of NICTs currently in progress is increasingly becoming a factor in either "stratification and marginalization or development and equality" (Warschauer, 2004: 210). Therefore, the political challenge we are facing, as far as technology is concerned, is inextricable from the expansion of NICT access and use as a social inclusion strategy, although that is not the only task ahead.

Thus, when measures and initiatives are undertaken to promote digital inclusion, the advantages deriving from the freedom to adapt copyleft licensed software - particularly with regard to the possibility of program customization - translate into an opportunity to make adjustments to a wide gamut of social, cultural and economic needs of individuals in different specific contexts (Silveira and Casino, 2003). For the fact is that, when compared with proprietary software or even with other information technologies, this adaptability is a lot more successful at giving prime focus to the issue "of social structures, social problems, social organization, and social relations" (Warschauer, 2004: 211), which are the determining factors behind the asymmetries and the poor distribution of resources and capabilities.

Taking into consideration the needs and interests of users in their particular contexts, free software makes it possible to develop communication, learning and discussion tools truly at the service of those who use them. By doing so, moreover, it opens up important alternatives to the sort of strategies of technology production and dissemination that reproduce social conditions and thus end up inhibiting development in its broader sense: the creation of social opportunities as well as the expansion of human capabilities and quality of life (Sen, 2000).

\section{Closing remarks}

This paper argues that free software culture does not have a secondary role in the context of the "new economy." On the contrary, it has played a leading role in the broad range of technological and social changes of the late $20^{\text {th }}$ century. It has also had, and continues to have, a significant impact on the restructuring of the capitalist economy, as a result of the technical and organizational innovations derived, both directly and indirectly, from such values as freedom and the sharing of information and knowledge.

Furthermore, the potential of free software culture for promoting development in and beyond the context of the "new economy" proves diversified and consistent in view of 
current social and economic challenges and needs, both in core regions and in regions less impacted by hegemonic globalization. More precisely, the flexibility of the software under analysis, which is based on the notion of free sharing, makes it adaptable to various contexts, be they economic - with potential benefits in terms of market-driven innovation or socio-cultural - by focusing development on reducing asymmetries, fostering inclusion, and bridging the digital divide.

Given the above, and to the extent that they can be both part of and apart from market dynamics, thus cutting their own semiautonomous path vis-à-vis hegemonic economic imperatives and the interests of governments, free software culture and its products prove to be instrumental not only for expanding substantive freedoms and capabilities but also in terms of obtaining social gains and (re)distributing informational power. As such, they are extremely relevant tools for implementing innovation - in the broad sense of the word - and for promoting Amartya Sen's principle of "development as freedom."

Translated by João Paulo Moreira

Revised by Teresa Tavares

\section{References}

Albagli, Sarita; Maciel, Maria Lucia (2011), "Informação, poder e política: a partir do Sul, para além do Sul," in Maria Lucia Maciel \& Sarita Albagli (eds.), Informação, conhecimento e poder: mudança tecnológica e inovação social. Rio de Janeiro: Garamond, 9-39.

Arbix, Glauco (2010), "Estratégias de inovação para o desenvolvimento," Tempo Social, 22(2): 167185.

Balducci, Jacqueline Rodrigues de Oliveira (2000), Sistema de informação: um breve histórico e sua aplicabilidade em bibliotecas universitárias. Itajubá: UNINCOR.

Baumgarten, Maíra; Santos de Lima, Leonardo (2014), "Inovação, inovação social e comunicação pública de ciência e tecnologia: o caso da Wikipédia e sua rede de atores," in Marcos Costa Lima \& Antonio Almeida Jr. (eds.), Comunicação, tecnologia e ambiente. São Paulo: Hucitec (forthcoming).

Bauman, Zygmunt (1998), Globalization: The Human Consequences. New York: Columbia University Press.

Benkler, Yochai (2006), The Wealth of Networks: How Social Production Transforms Markets and Freedom. New Haven: Yale University Press.

Best, Steven; Kellner, Douglas (2001), The Postmodern Adventure. Science, Technology, and Cultural Studies at the Third Millennium. New York: The Guilford Press.

Black, John (2009), A Dictionary of Economics. Oxford: OUP [ $3^{\text {rd }}$ ed.]

Breton, Philippe (1991), História da informática. São Paulo: UNESP.

Campos, Aline de (2009), "Conflitos na colaboração: um estudo das tensões em processos de escrita 
coletiva na web 2.0." Master's Thesis. Porto Alegre, Brazil: Universidade Federal do Rio Grande do Sul.

Cardon, Dominique (2012), A democracia internet: promessas e limites. Rio de Janeiro: Forense Universitária.

Castells, Manuel (2001), The Internet Galaxy: Reflections on the Internet, Business, and Society. New York: Oxford University Press.

Castells, Manuel (2010), The Rise of the Network Society. The Information Age: Economy, Society and Culture. Vol. I. Chichester, West Sussex, UK: Wiley-Blackwell $\left[2^{\text {nd }}\right.$ ed.].

Chopra, Samir; Dexter, Scott D. (2010), Decoding Liberation. The Promise of Free and Open Source Software. New York: Routledge.

Cocco, Giuseppe (2011), "A luta dentro do novo paradigma. Revisitando o debate sobre inovação," in Maria Lucia Maciel \& Sarita Albagli (eds.), Informação, conhecimento e poder: mudança tecnológica e inovação social. Rio de Janeiro: Garamond, 103-149.

Coleman, Enid Gabriella (2010), "Revoluções silenciosas: o irônico surgimento do software livre e de código aberto e a constituição de uma consciência legal hacker," in Ondina Fachel Leal \& Rebeca Hennemann Vergara de Souza (eds.), Do regime de propriedade intelectual: estudos antropológicos. Porto Alegre: Tomo Editorial, 131-147.

Ferraz, Nelson Corrêa de Toledo (2002), "Vantagens estratégicas do software livre para o ambiente corporativo." Master's Thesis in Business Information Systems. São Paulo, Brazil: Pontifícia Universidade Católica.

Guesser, Adalto Herculano (2011), Software livre \& controvérsias tecnocientíficas: uma análise sociotécnica no Brasil e em Portugal. Curitiba: Juruá.

Johnson, Telma (2010), Nos bastidores da wikipédia lusófona: percalços de um projeto de escrita coletiva on-line. Rio de Janeiro: E-papers.

Julien, Pierre-André (2010), Empreendedorismo regional e economia do conhecimento. São Paulo: Saraiva.

Kellner, Douglas (2002), “Theorizing Globalization," Sociological Theory, 20: 285-305.

Kellner, Douglas (2003) "Media Culture and the Triumph of the Spectacle," in Media Spectacle. London: Routledge, 1-33.

Kelty, Christopher M. (2008), Two Bits: The Cultural Significance of Free Software. Durham: Duke University Press.

Maciel, Maria Lucia (2005), "Estímulos e desestímulos à divulgação do conhecimento científico," in Maíra Baumgarten (ed.), Conhecimentos e redes: sociedade, política e inovação. Porto Alegre: UFRGS Editora, 107-136.

Martín-Barbero, Jesús (2006), "Tecnicidades, identidades, alteridades: mudanças e opacidades da comunicação no novo século," in Dênis de Moraes (ed.), Sociedade midiatizada. Rio de Janeiro: Mauad, 51-79.

Mendes, Cássia Isabel Costa (2006), "Software livre e inovação tecnológica: uma análise sob a perspectiva da propriedade intelectual." Master's Thesis. Campinas, Brazil: Unicamp.

Miranda, Viviane Vieira de; Vieira, Carlos Eduardo da Costa; Carelli, Flávio Campos (2008), "O uso de Software Livre no Serviço Federal de Processamento de Dados (Serpro)," Cadernos UniFOA, 3(8): 11-20.

Murillo, Luis Felipe Rosado (2010), "Tecnologia, política e cultura na comunidade brasileira de software livre e de código aberto," in Ondina Fachel Leal \& Rebeca Hennemann Vergara de Souza 
(eds.), Do regime de propriedade intelectual: estudos antropológicos. Porto Alegre: Tomo Editorial, 75-93.

Negroponte, Nicholas (1995), Being Digital. New York: Knopf.

O'Reilly, Tim (2005), "What Is Web 2.0 - Design Patterns and Business Models for the Next Generation of Software," O'Reilly Media Inc. Accessed on 03.02.2014, at http://oreilly.com/web2/archive/what-is-web-20.html.

Orozco Gómez, Guillermo (2006), "Comunicação social e mudança tecnológica: um cenário de múltiplos desordenamentos," in Dênis de Moraes (ed.), Sociedade midiatizada. Rio de Janeiro: Mauad, 81-98.

Santos, Boaventura de Sousa (2011), "Os processos da globalização," in Boaventura de Sousa Santos (ed.), A globalização e as ciências sociais. São Paulo: Cortez, 25-102 [4 ${ }^{\text {th }}$ ed.].

Sassen, Saskia (2011), "Conhecimento político informal e seus efeitos capacitantes: o papel das novas tecnologias," in Maria Lucia Maciel; Sarita Albagli (eds.), Informação, conhecimento e poder. Mudança tecnológica e inovação social. Rio de Janeiro: Garamond, 151-182. English version: "Informal Political Knowledge and its Enablements: The role of the new technologies," available at http://future-nonstop.org/c/f7b7089f10dec03d5e8a5cf8d9f8dad2.

Sen, Amartya (2000), Development as Freedom. New York: Anchor Books.

Silveira, Sérgio Amadeu (2003), "Inclusão digital, software livre e globalização contra-hegemônica," in Sérgio Amadeu Silveira \& João Cassino (eds.), Software livre e inclusão digital. São Paulo: Conrad Editora do Brasil, 17-47.

Silveira, Sérgio Amadeu (2004), Software livre: a luta pela liberdade do conhecimento. São Paulo: Editora Fundação Perseu Abramo.

Silveira, Sérgio Amadeu; Cassino, João (eds.) (2003). Software livre e inclusão digital. São Paulo: Conrad Editora do Brasil.

Warschauer, Mark (2004), Technology and Social Inclusion: Rethinking the Digital Divide. Cambridge, MA: MIT Press. 